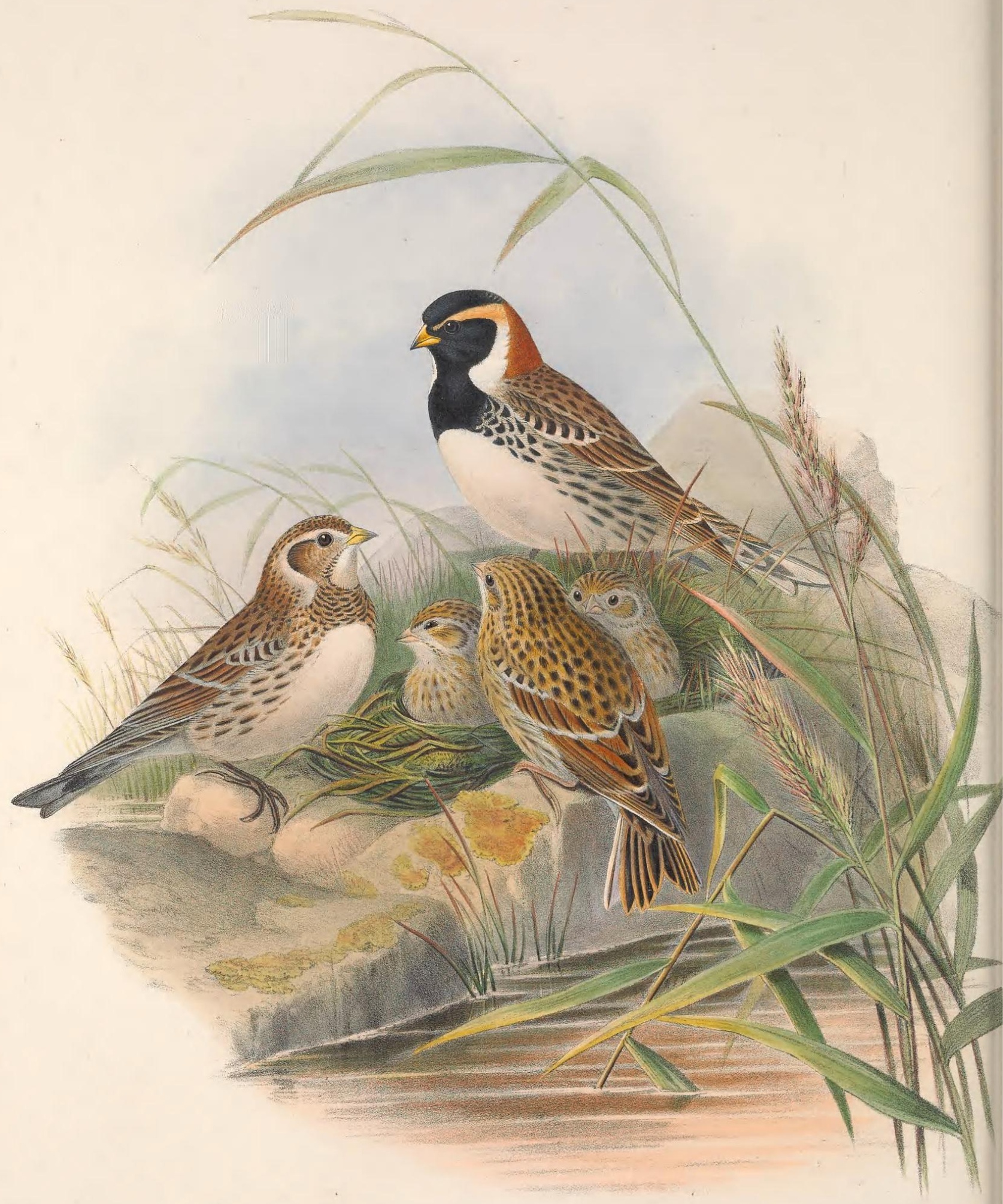




\section{CEN'TROPHANES LAPPONICA.}

\section{Lapland Bunting.}

Emberiza lapponica, Nilss. Orn. Suec., tom. i. 157.

Fringilla calcarata, Pall. Itin., tom. ii. p. 710.

lapponica, Gmel. edit. Linn. Syst. Nat., tom. i. p. 90.

Emberiza calcarata, Temm. Man. d'Orn., p. 190.

Plectrophanes lapponica, Selby, Trans. Linn. Soc, vol. xv. p. 156, pl. 1.

calcaratus, Meyer, 3. Theil des Taschenb. Deutschl. Vög., p. 57.

Centrophanes lapponica, Kaup, Natürl. Syst., p. 158.

From the date, now somewhat more than forty years ago, when Mr. Selby first assigned this species a place in our avifauna, many examples have been shot or captured in this country. In most instances they were either immature or in the winter dress; it is evident, therefore, that the British Islands are not the bird's summer home, and that its occurrence here must be regarded as purely accidental. The specimen characterized by Mr. Selby had been sent to Leadenhall market with some Larks from Cambridgeshire ; a second and a third were taken near Brighton; a fourth a few miles northward of London; a fifth in Lancashire, and a sixth in Westmoreland. During the antumn of 1866 one was canght near Highgate, and subsequently placed in the aviary of the Zoological Society; and another is recorded by Mr. Cooke, of Liskard, as liaving been purchased in the Liverpool market from a Southport bird-catcher. Mr. Stevenson, of Norwich, also records that a male was taken, during extremely severe weather, at Postwick, near that city, and, being placed in the aviary of J. H. Gurney, Esq., assuned the full summer plumage in the following spring. "The only other Norfolk specimen of this Bunting I have either seen or heard of," says Mr. Stevenson, "was shown to me by the Rev. E. J. Bell; it had been netted near Norwich, a few weeks before, and was gradually assuming its summer plumage, having the black on the head and throat imperfect, with a chestnut bar on the nape." There may be some other instances of its having been taken with us ; but sufficient has been said to establish the Lapland or Lark-heeled Bunting as an occasional visitant to Britain. Its true home is whither the Fieldfare, the Redwing, and the lovely Blue-throated Warbler (Cyanecula suecica) retire for the purpose of incubating - the land of the Lap and the Lemming. There it breeds in abundance ; and if any son of Britain desires to observe the bird during the performance of this duty, he must leave for a while the song of the Lark and the tinkle of the sheep-bell, and betake himself to the fells, the fjelds, and fjords of Norway, Finland, and Lapland, and dwell for a time among the nomadic races of those countries and their herds of reindeer; and how much pleasure he may derive thereby will be readily apparent from the following chapter from Mr. Wheelwright's papers entitled "Spring and Summer in Lapland," which appeared in the Field for March 31, 1863, and which cannot fail to be interesting to every one desirous of information respecting this bird :-

"The Lapland Bunting appeared to arrive at Quickiock later than any other species, and, unlike the ShoreLark, did not rest in the lowlands, but went up to the fells at once; I don't think we saw six examples at Quickiock the whole spring, whereas in the middle of June they were literally swarming in certain places on the fellmeadows - so much so that in one night we took thirteen nests, from all of which we shot the old birds. They seemed, however, to be very local; and it was long before we could discover their breeding-place. At last we found a low flat at the foot of the highest snow-fells (but still, perhaps, 2000 feet above Quickiock), covered with tough tussocky grass and patches of willow bushes, and studded with innumerable lakes and watercourses. This was a rich tract to us; for here we also found the nests of the Blue-throated Warbler, Broad-billed Sandpiper, Temminck's Stint, Wood-Sandpiper, Phalarope, Scaup and Long-tailed Ducks. It is one of the sweetest spots that can well be imagined - a real oasis in the desert; and I never enjoyed a summer ramble so much as in this wild tract. There are certain circumstances in life, as well as places, which leave an impression on the mind never to be obliterated; and this fell-meadow forms one of the brightest flowers in the field of memory as regards my Lapland journey.

"When I first searched this spot I was attracted by a soft loud pipe, very much resembling the call of the Golden Plover. It was long before I could make it out ; for I could not see the bird which uttered it : at last one rose, and I shot it on the wing; it proved to be a male Lap Bunting. The mystery was now solved; and we had no difficulty in finding the nest, as it was not far off: and I soon became more familiar with its habits. The female rarely rises, unless you tread close to the nest, but runs away on the ground, much like the Pipit. The male sits on a stone or heap of earth, uttering his monotonous, plaintive whistle, till disturbed, when he rises in the air, much after the manner of the Common Bunting, soars for a while, and then suddenly drops to the ground, as a Skylark does into a field of young wheat in England. While in the air the song of the Lap- 
land Bunting is richer and clearer than that of any other of our songsters-not so shrill as that of the Lark, but far sweeter and more varied; and I thought I never listened to a more pleasing melody. Oh, how often have I at such times envied the feelings of the true naturalist, who can listen to the artless song of the little bird without wishing it in his game-bag, and watch its habits without hoping soon to see it lying on his skinuingtable! There must, however, be collectors, or our knowledge of the feathered race would stand still; but, depend upon it, the study of the animal creation loses half its innocent charms as soon as we make it a matter of pounds, shillings, and pence.

"The nest of the Lapland Bunting, as far as I could ascertain, is always placed on the ground, generally sheltered by a tussock of grass, occasionally under a small bush, built iuvariably and entirely of fine grass, put together loosely and without much care. The eggs vary much in colour; they often resemble those of the Black-headed Bunting, but are more clouded than streaked; and I have seen them very like those of the Meadow-Pipit. Six appears to be the full number. By the end of July we shot strong-flyers, although most of the nests were taken about the 27 th June."

I have often been at a loss to imagine where these birds dwell at the season opposite to that at which they are seen on the Quickiock fells and other parts of Norway, Finland, and Russia. They certainly cannot winter in those regions; and I know of no country in which they have been seen at that season. In Central and Southern Europe the species appears to be but a casual winter visitant, while in India it is not known; and Mr. Swinhoe does not speak of it as inhabiting the sonthern part of China, although he says that it is abundant near Pekin in winter; but doubtless these are birds which have bred further north. Professor Baird, in his ' Catalogue of American Birds,' gives as its habitat in that country, " Eastern North America, into the U'nited States in winter ; not yet found much west of the Missouri."

As a counterpart to Wheelwright's account of the bird in Northern Europe, I shall quote a passage from Sir John Richardson, in the 'Fauna Boreali-Americana,' respecting it as seen in that part of the world:-

"This handsome bird is common to the northern regions of both continents. According to Forster, it winters on the coast of Hudson's Bay, arriving at Severn River in November, and departing on the approach of spring for the north. During its stay it feeds on grass-seeds and, Hearne says, also on the buds of the Pinus microcarpa.. . . I I never met with it in the interior of the fur-countries during winter, and I suspect that its principal retreats at that season are on the borders of Lakes Huron and Superior, and to the country extending to the westward on the same parallel. In the year 1827 it appeared on the plains at Carltou House about the middle of May, in very large flocks, among which were many Shore-Larks (Alauda alpestris), and a few individuals of Plectrophanes picta. During their stay of ten or twelve days, they frequented open spots where recent fires had destroyed the grass. They came to Cumberland House a few days later in the same season, and there kept constantly in the furrows of a newly-ploughed field. In the preceding year they were seen, though in smaller flocks, in the vicinity of Fort Franklin (lat. $65 \frac{1}{2}^{\circ}$ ) in the beginuing of May; and the crops of those that were then killed were filled with the seeds of the Arbutus alpina. They breed in the moist meadows of the Arctic Sea. The nest, placed in a small hillock, among moss and stones, is composed. externally of the dry stems of grasses, interwoven to a considerable thickness, and lined rery neatly and compactly with deer's hair. The eggs, usually seven in number, are pale ochre-yellow, spotted with brown."

After a perusal of the above passages, it will be evident to every one that the Lapland Bunting is truly an Arctic species, that it breeds and spends the summer in all parts of the Circle where suitable localities present themselves, and that when the snow carpets the mountains, and the fells are covered up for the winter, it retires southwardly to some district where a supply of food is still to be found, and there awaits the time when its summer home will be again fitted for its reception.

A word with regard to the apparent affinities of this bird may not here be inappropriate. That it is closely allied to that section of the Buntings to which our black-headed species, Schoenicola arundinacea, pertains, there can be, in my opinion, but little doubt; but its long hind claw proves that it is generically distinct; in this part of its structure it differs from all insessorial birds except the Larks, Pipits, and Wagtails. Some persons have considered that the lengthened claw allies it to the members of the genus Alauda or true Larks; but, as Mr. Blyth very justly remarks, this is very superficial. It is a bird that is much on the ground, over which it passes differently from most others; for it neither runs like a Lark or a Wagtail, nor hops like a Sparrow, but moves iu a manner which partakes of the actions of both. I have reason to believe that a considerable change of plumage takes place in the male at opposite periods of the year, and that the black head and throat, and the ruddy markings of the upper surface, shown in the accompanying plate, give place to a more uniformly coloured dress in winter.

The figures represent a male, a female, and a brood of young just ready to fly, all of the natural size. 


\section{$2 \mathrm{BHL}$ Biodiversity Heritage Library}

Gould, John. 1873. "Lapland Bunting, Centrophanes lapponica [PI. 30]." The birds of Great Britain 3, -. https://doi.org/10.5962/p.323921.

View This Item Online: https://www.biodiversitylibrary.org/item/221726

DOI: https://doi.org/10.5962/p.323921

Permalink: https://www.biodiversitylibrary.org/partpdf/323921

\section{Holding Institution}

Smithsonian Libraries

\section{Sponsored by}

Biodiversity Heritage Library

\section{Copyright \& Reuse}

Copyright Status: Public domain. The BHL considers that this work is no longer under copyright protection.

This document was created from content at the Biodiversity Heritage Library, the world's largest open access digital library for biodiversity literature and archives. Visit BHL at https://www.biodiversitylibrary.org. 